\title{
Three-dimensional Educational Technology for the prevention of accidents caused by falls in the elderly
}

\author{
Tecnologia educacional tridimensional para prevenção de acidentes por quedas em idosos \\ Tecnología educacional tridimensional para prevención de accidentes por caídas en ancianos
}

\author{
Rayanne Branco dos Santos Lima' \\ ORCID: 0000-0002-6287-4606 \\ Rachel Gabriel Bastos Barbosa' \\ ORCID: 0000-0003-4205-6910 \\ Jamylle Lucas Diniz' \\ ORCID: 0000-0002-5697-8599 \\ Joyce da Silva Costa' \\ ORCID: 0000-0001-6481-3682 \\ Marília Braga Marques' \\ ORCID: 0000-0002-7483-1435 \\ Janaína Fonseca Victor Coutinho' \\ ORCID: 0000-0001-7451-0132
}

'Universidade Federal do Ceará. Fortaleza, Ceará, Brazil.

How to cite this article:

Lima RBS, Barbosa RGB, Diniz JL, Costa JS, Marques MB, Coutinho JFV. Three-dimensional Educational Technology for the prevention of accidents caused by falls in the elderly.

Rev Bras Enferm. 2021;74(Suppl 5):e20190806. doi: http://dx.doi.org/10.1590/0034-7167-2019-0806

Corresponding author: Jamylle Lucas Diniz E-mail: jamylledz@hotmail.com

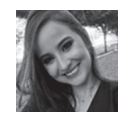

EDITOR IN CHIEF: Dulce Barbosa ASSOCIATE EDITOR: Priscilla Broca

Submission: $03-02-2020$

Approval: 09-07-2020

\section{ABSTRACT}

Objective: Evaluate a three-dimensional educational gerontotechnology for the prevention of falls in the elderly at home. Methods: Cross-sectional, descriptive study, involving the Development of gerontotechnology; Evaluation by specialists and target audience, took place in Fortaleza, State of Ceara, Brazil, from June 2017 to October 2018. For the development, it was used the steps adopted in a booklet and the Casa Segura project for the elderly. 16 specialists and 30 elderly participated in the evaluation, using the Health Promotion Model, by Nola Pende. Results: The scale model has an area of $160 \mathrm{~cm}^{2}$, with four rooms made of Medium Density Fiberboard. Specialists consider technology adequate, with a level of compliance of $87.7 \%$ IC95\% $[87,71-88,42]$. All the elderly related that the scale model looked their homes, and 13 of them (43.3\%) suggested the construction of a backyard, a possible second floor, corridors, and stairs. Conclusion: Gerontotechnology was considered fit to be used in the prevention of falls in the elderly.

Descriptors: Nursing; Elderly; Accidents by Falls; Educational Technology; Health Promotion.

\section{RESUMO}

Objetivo: Avaliar uma gerontotecnologia educacional tridimensional para prevenção de quedas em idosos no domicílio. Métodos: Estudo transversal, descritivo, compreendendo Desenvolvimento de gerontotecnologia; Avaliação por especialistas e público-alvo — realizado em Fortaleza, Ceará, Brasil, de junho de 2017 a outubro de 2018. Para o desenvolvimento, utilizaram-se os passos adotados em uma cartilha e o projeto Casa Segura para idosos. Participaram da avaliação 16 especialistas e 30 idosos, utilizando o Modelo de Promoção da Saúde, de Nola Pender. Resultados: A maquete possui área de $160 \mathrm{~cm}^{2}$, com quatro cômodos em material do tipo Medium Density Fiberboard. Os especialistas consideraram a tecnologia adequada, com nível de concordância de $87,7 \%$ IC95\% [87,71-88,42]. Todos os idosos relataram que a maquete se assemelhava ao seu domicílio, e 13 destes $(43,3 \%)$ sugeriram a construção de um quintal, possibilidade de dois andares, corredores e escadas. Conclusão: A gerontotecnologia foi considerada apta para utilização na prevenção de quedas em idosos. Descritores: Enfermagem; Idoso; Acidentes por Quedas; Tecnologia Educacional; Promoção da Saúde.

\section{RESUMEN}

Objetivo: Evaluar gerontotecnología educacional tridimensional para prevención de caídas en ancianos en domicilio. Métodos: Estudio transversal, descriptivo, comprendiendo Desarrollo de gerontotecnología; Evaluación por especialistas y público objeto — realizado en Fortaleza, Ceará, Brasil, de junio de 2017 a octubre de 2018. Para el desarrollo, utilizaron los pasos adoptados en una cartilla y el proyecto Casa Segura para ancianos. Participaron de la evaluación 16 especialistas y 30 ancianos, utilizando el Modelo de Promoción de la Salud, de Nola Pender. Resultados: La maqueta posee área de $160 \mathrm{~cm}^{2}$, con cuatro cómodos en material del tipo Medium Density Fiberboard. Los especialistas consideraron la tecnología adecuada, con nivel de concordancia de $87,7 \%$ IC95\% [87,71-88,42]. Todos los ancianos informaron que la maqueta se asemeja al domicilio, y 13 de estos (43,3\%) sugirieron la construcción de un patio, posibilidad de dos pisos, pasillos y escaleras. Conclusión: La gerontotecnología ha considerada apta para utilización en la prevención de caídas por ancianos.

Descriptores: Enfermería; Anciano; Accidentes por Caídas; Tecnología Educacional; Promoción de la Salud. 


\section{INTRODUCTION}

Regarding healthcare, it is crucial to qualify care, taking into consideration the necessity to translate the technical-scientific knowledge in tools, processes, and materials ${ }^{(1)}$, highlighting the articulation of practices and knowledge, innovations and use of technologies.

Among the existing technologies, the educational refers to strategies for innovation of education, with the use of tools to mediate the teaching and learning processes ${ }^{(2)}$. Applied to gerontology, gerontotechnology is an area of interdisciplinary interest that involves scientific study for improvement of techniques, products and services based on the knowledge of the aging processes ${ }^{(3)}$. In this sense, educational gerontotechnology encompass a set of knowledge, devices, processes, and strategies that aim new possibilities of teaching and learning, through the valorization of the relationships and interactions between the professional, the elderly and the family ${ }^{(4)}$.

Among the relevant demands for using educational gerontotechnologies are the actions to prevent falls. This harm includes non-intentional misplacement of the body to a level lower to the initial position with incapacity of correction in a timely manner, caused by multifactorial circumstances that compromise stability ${ }^{(5)}$.

Fall is the main cause of death from injuries, non-fatal injuries, and hospital admissions, affecting one in three elderly people $\mathrm{e}^{(6)}$. One-third of the community's long-lived people fall at least once a year ${ }^{(7)}$. Falls directly affect the quality of life of the elderly, their families, caregivers, in addition to involving high personal, social, and economic costs ${ }^{(8)}$.

It is believed that training and three-dimensional view may be effective in the prevention of falls in the care for the long-lived people ${ }^{(9-10)}$. The use of three-dimensional view provides visual quality necessary to conceptualize the information mediated by the health professional, becoming the best two-dimensional technologies for providing immersion and representation of reality ${ }^{(11)}$.

In order to facilitate and subsidize the internalization of knowledge about falls risk, or any other aspect that aims to promote health, it is necessary to use theoretical support that helps and enhances. Among the theoretical models used in nursing and in behavioral sciences, the model presented by Nola J. Pender stands out. It approaches a structure to assimilate attitudes about effective factors in healthy behavior, acting as a guide for educational processes, in order to encourage the involvement of individuals. This model emphasizes health promotion behaviors, recognizing them associated to personal factors with greater efficiency and perception, reforming and strengthening communication ${ }^{(12)}$.

The development of three-dimensional educational gerontotechnologies attached to a robust theoretical support may be an innovative tool in the clinic practice of nurses and other health professionals with regard to the prevention of falls, thus constituting an increase in health care for the elderly.

\section{OBJECTIVE}

Evaluate a three-dimensional educational gerontotechnology for the prevention of falls in the elderly at home.

\section{METHODS}

\section{Ethic Aspects}

The development of the survey met the National standard in survey ethics involving human beings, and it was approved by the Ethics in Survey Committee, which opinion was sent in document attached to the submission process.

\section{Design, place of study, and period}

Cross-sectional, descriptive study that encompassed: Development of three-dimensional gerontotechnology; Evaluation by specialists; and Evaluation by the target audience. It was guided by the instrument Strengthening the Reporting of Observational Studies in Epidemiology (STROBE) ${ }^{(13)}$.

The application of simulators proved to be effective ${ }^{(14)}$ for preventing falls in the elderly, however they have a high production cost, which makes it difficult for professionals to adhere as a means of promoting health ${ }^{(15)}$. In this study, in view of the cost-benefit ratio among the three-dimensional devices available, the scale model was chosen as an educational resource, as it is able to represent projection, proportion, orientation, height and depth - crucial aspects, for the elderly in terms of fall risk ${ }^{(16)}$.

The study took place from June 2017 to October 2018, in the city of Fortaleza, State of Ceara, Brazil. The development of the scale model happened between June and November 2017. The furniture manufacture started in December 2017 until January 2018. Specialists' evaluation took place from February to June 2018; the adjustments to the scale model resulting from the evaluation of the judges were made in the period of July and August 2018; and the application with the target audience occurred in September 2018.

\section{Population or sample; inclusion and exclusion criteria}

The evaluation of educational gerontotechnology was held by 16 specialists $^{(17)}$. There is no uniformity in the number of specialists needed to evaluate a technology, the number of which can vary from 3 to $16^{(18)}$. These were selected through snowball sampling ${ }^{(19)}$ and met at least two of the following criteria of eligibility: care experience with the elderly; participation in falls prevention actions in the elderly; experience with development of technologies; stricto sensu graduate program with production in gerontology, gerontotechnology or fall prevention. This information was consulted in the Lattes Curriculum. The Consent Document (TCLE) and invitation letter were sent via email that, upon acceptance, a video was sent containing the scale model with animations of all rooms, its area, perimeter, high and depth measurements, and characteristics of the furniture such as type, size, depth, along with the evaluation instrument.

The gerontotechnology evaluation by the target audience had the participation of 30 elderly divided in five groups with six participants, and it was held in a Primary Care Unit in the municipality of Fortaleza, State of Ceara, during the collection period. The activity lasted approximately 30 minutes. It included elderly with 60 years old or older, excluding elderly with severe 
visual and/or hearing impairment or other conditions that would make the communication impossible. At the end, six elderly were excluded for presenting severe communication difficulties.

\section{Study Protocol}

For the elaboration of the scale model, it was used the booklet recommendations "Steps for the prevention of falls in the elderly" and the Project "Safe home for the elderly"(20-21), which helped in the idealization of the number and arrangement of the rooms, manufacture of the furniture and accessories, with regard to the type, quantity and dimensions.

Then, an architect designed the floor plan of a house with the following rooms: dining room, kitchen, bedroom and bathroom. The floor plan was delivered to an expert professional who constructed the scale model with material of the type Medium Density Fiberboard (MDF), a mix of wood fibers pressed with re$\sin$. The furniture was manufactured with the same material by means of laser cutting. The furniture dimensions followed the scale 1:10, in which each centimeter of the furniture matches to $10 \mathrm{~cm}$ of the efficient recommended by the Project "Safe home for the elderly"(20-21).

It was manufactured two sofas, one rack, a dining table with four chairs, a fridge, a stove, a sink, a set of table and chairs, two wardrobes, a bed, a lamp, a dressing table, an armchair, a bathroom, a shower and safety bars. It was also used a plastic dog, carpets, and a fabric hammock.

For the evaluation by the judges, the instrument included the aspects: dimensions, furniture layout, applicability and cultural adequacy. The answers were categorized in the level of agreement from 1 to 5 , being: 1, I totally disagree; 2 , disagree; 3 , neither agree nor disagree; 4 , agree; 5 , totally agree. An agreement level of $85 \%$ or greater was adopted to consider the domain evaluated as apt.

The target audience conducted the evaluation of the scale model with its furniture and accessories, which was arranged on a table in a reserved environment.

To subsidize the use of the scale model as educational gerontotechnology, it was used the theoretical reference of the Health Promotion Model (MPS), by Nola J. Pender, which presents three components: (1) Individual Characteristics and Experiences refer to the previous behavior that must be changed and to its personal factors involved; (2) Feelings and knowledge regarding Specific Behavior are the perception of benefits for action, like positive mental representations that reinforce the adoption of a behavior, and perception of barriers for action, which consist in the real or imaginary existence of difficulties, inconveniences, wasting of time and obstacles, perception of self-efficacy; and (3) Desirable Health Promotion Behavior refers to the health promotion behavior that you want to achieve ${ }^{(22)}$.

These components were represented in a form containing the following questions: (1) Individual experiences: Does this scale model resemble to your home or somebody's home that you know? Are the furniture and accessories present in your home? Did you fall in the last year? If yes, where did it happen? (2) Specific behavior: Could you point out what would make it easier the occurrence of falls in each room? What can inhibit risk reduction in your home? How can these changes help prevent risk? (3) The expected result: What behaviors would you adopt to reduce the falls risk?

The questions were registered by the researchers. The answers options for the component 1 were dichotomous (yes or no), and the answers of component 2 and 3 were open.

\section{Results analysis and statistics}

The data was organized in Microsoft Excel 2010 and analyzed in the statistical package $\mathrm{R}^{\circledast}$ version 3.6.3, using descriptive statistics and confidence intervals.

\section{RESULTS}

The scale model has $10 \mathrm{~cm}$ depth, in a total area of $160 \mathrm{~cm}^{2}$, divided in four rooms: living room, kitchen, bedroom and bathroom. Its total weight is 3,000 grams. The living room has a perimeter of $186 \mathrm{~cm}$, in a rectangular shape with dimensions of $60 \mathrm{~cm} \times 33$ $\mathrm{cm}$, as well as the kitchen, which dimensions are $60 \mathrm{~cm} \times 27 \mathrm{~cm}$, with perimeter of $132 \mathrm{~cm}$. The bedroom has a "L" format, with perimeter of $140.5 \mathrm{~cm}$. The bathroom has a rectangular space, with perimeter of $105 \mathrm{~cm}$ (Figure 1).

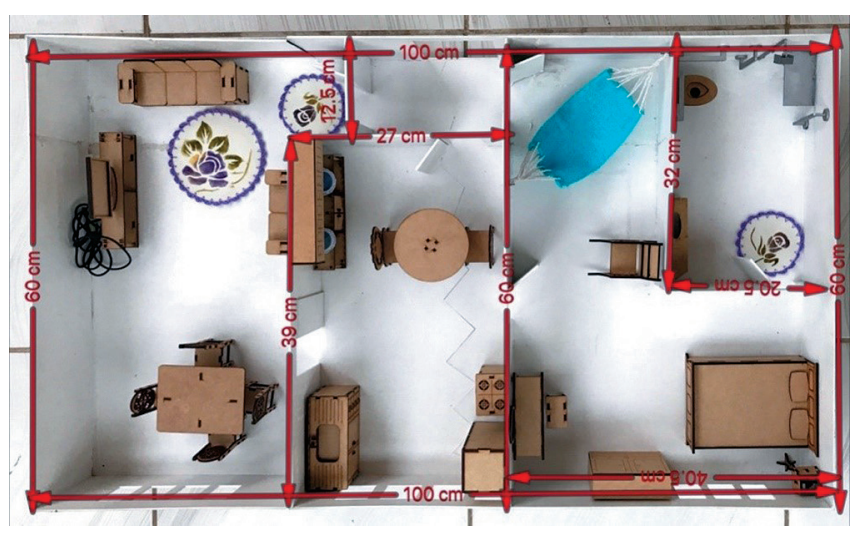

Figure 1 - Upper vision of the scale model and respective measurements in centimeters $(\mathrm{cm})$

Regarding the furniture, the pieces with seat purpose (chairs, armchairs, bed, sofa and toilet) were manufactured with a height of $4.5 \mathrm{~cm}$. Those that serve as support (tables and dressing table) and of orthostatic use (sinks and stove) were $7.5 \mathrm{~cm}$ high. In addition, the lamp was $7 \mathrm{~cm}$ high; and the fridge, $10 \mathrm{~cm}$. Such furniture was disposed in the rooms, living room, kitchen, and bedroom. It should be noted that, in the bathroom, were installed support bars and bath seat $(4.5 \mathrm{~cm})$ (Figure 2).

The scale model was evaluated by 16 specialists whose ages varied from 27 to 56 years old ( $M=42,75$; $D P= \pm 11.27$ years). Among them, 13 (81.3\%) were female and 3 (18.7\%) male; 9 (56.2\%) nurses, 5 (21.2\%) physiotherapists, and 2 (12.5\%) doctors; 12 (75\%) had master's degree, and 6 (37.5\%) had a doctorate. Regarding the experience in years for caring for the elderly, five (31.2\%), had between 5 and 9 years and one (6.2\%) had between 1 and 4 years. Regarding the experience with educational technologies, 15 (93.8\%) reported participation in the making or evaluation. All specialists reported publications focused on the health of the elderly and participation in survey groups. 

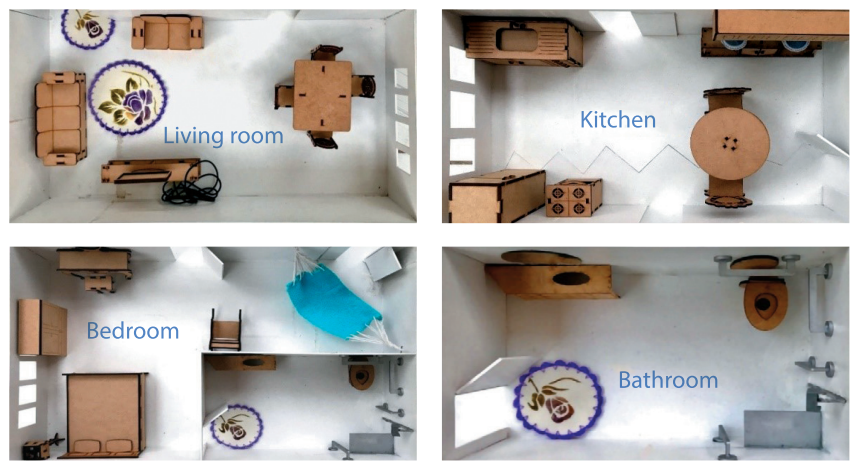

Figure 2 -Upper Vision of the rooms and disposition of the furniture in the scale model

In their evaluations, the specialists made suggestions regarding the arrangement of the furniture and carpets, namely: In the living room - Let the wire behind the TV hold and, only at the time of use, release them to demonstrate the risks; In the kitchen - Place the stove next to the sink; in the bedroom - Bring the wardrobe closer to the bed to make it easier to get ready and advise on the fall risk out of the hammock; In the bathroom - Remove the carpets and emphasize the use of a non-slippery floor. As general guidance, specialists reinforced the need for lightning and the addition of a service area.

The scale model was considered valid as an educational gerontotechnology in the prevention of falls of the elderly, having an average level of compliance of $87.7 \%$ IC95\% [82,71-88,42]. The level of compliance regarding the evaluation of each room is shown in the Figure 3.

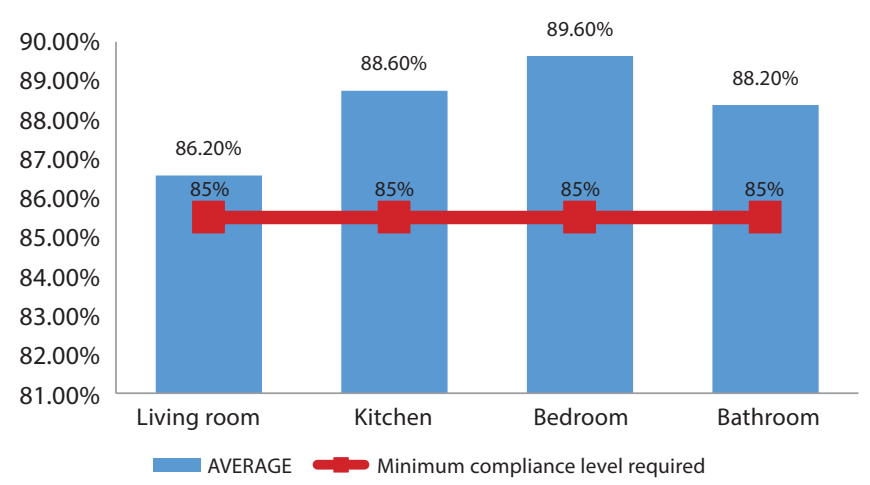

Figure 3 - Compliance level regarding the evaluation of the scale model rooms, Fortaleza, State of Ceara, Brazil, 2018

Out of 30 elderly that evaluated the scale model, 18 (60\%) were female, and 12 (40\%), male; 17 (56.7\%) aged between 60 and 69 years old, and 13 (43.3\%), between 70 and 79 years old. Regarding schooling, 12 (40\%) had from 4 to 8 years of schooling; 5 (16.7\%) between 1 and 3 years; and 3 (10\%), less than 1 year of schooling. About the income, 19 (63.3\%) received between one and two minimum salaries, while $5(16.7 \%)$, between three and four salaries. And about the presence of chronic diseases, 26 (86.7\%) had them, and 4 (13.3\%) did not or did not know if they had.

All thirty elderly people reported that the scale model, the furniture, and the accessories resemble those of their homes, except the lamp. Six elderly (20\%) suggested the manufacture of a microwave for the kitchen. Despite the similarity of the scale model to their homes, 13 (43.3\%) elderly suggested the construction of a service area/backyard, and the possibility to have a second floor, corridors and stairs.

Regarding falls in the last year, 17 (56.7\%) fell at least once, three of them (10\%) were hospitalized in consequence of the fall. Of those who reported falls, 10 (58.9\%) fell in the bathroom; 5 (29.4\%), in the service area/backyard; 1 , in the bedroom; and 1 reported fall out of home. According to the answers, participants used the scale model to demonstrate the furniture disposition in their home environment, explain in which room and how the fall happened, and what are the possible aspects that could have influenced this outcome.

Using the scale model, the elderly pointed the risk factors as the hammock, the dog, the carpet, the wires, and indicated the bathroom the most accident-prone place. The use of the bars was pointed as a protection element for all the elderly. However, only one elderly lady mentioned to have safety bars in her bathroom. Although they recognize the bars are important, they mentioned the financial resources for the installation as barriers to health-promoting behavior. The disposal of furniture was not identified as a risk factor.

All the points referring to risk factors not identified by the elderly, were pointed out and demonstrated in the scale model by the researchers. At the end of the use of the scale model by the 30 elderly participants, 22 (73.3\%) were able to point out the main risk factors and report which health-promoting behaviors would be necessary at their homes to avoid falls: avoid carpets, placement safety bars in the bathrooms, avoid step on the wet floor, stairs, wires, and pets.

\section{DISCUSSION}

For the effectiveness of health-promoting strategies, interdisciplinary actions are necessary with regard to public management, as well as the creation and implementation of health and environment policies. The prevention of falls in the elderly is included in the reality of these strategies and, as such, it requires actions that go beyond the health sector in order to be really effective. However, the increased perception of fall risk with respect to extrinsic factors is able to reduce exposure to its triggering factors ${ }^{(23)}$, since they are the easiest factors to be identified and intervene, in order to avoid the event and ensure longer functional capacity for the elderly.

From this perspective, three-dimensional technologies are innovative and effective tools in educational processes, as they can mediate practices and guidelines, enabling the understanding of information with greater interactivity ${ }^{(24)}$.

The use of three-dimensional gerontotechnology of scale model type enable demonstrate preventive strategies, contributing to the visualization of the falls risk in the elderly at home. Its use together with guidelines oriented by health professionals help to reduce expenses with hospitalization, surgeries and rehabilitation, in addition to improving quality of life ${ }^{(25)}$. Clinical trial conducted in Japan using a model to prevent falls in the elderly revealed that this gerontechnology favors solid, dynamic and interactive learning, being able to reduce the occurrence of this disease ${ }^{(26)}$. 
Home is considered the most favorable place for falls in the elderly population, since, in this environment, attention decreases for activities that occur routinely ${ }^{(27)}$. Visualizing the risks in this scenario helps in the internalization of prevention attitudes, strengthening health-promoting behaviors. Environmental changes for the prevention of falls may help not only the elderly, but also the other residents that will also pass through the same aging process.

The scale model built in this studio was considered fit to be used as educational gerontotechnology in the prevention of falls. The contribution of specialists in this process stands out, who are in charge of assessing the quality of the material produced. For the choice of professionals, we recommend: the importance of professional experience, either assistance or teaching, with publications and citations by other researchers in the area of knowledge $\mathrm{e}^{(28)}$; and the diversity of specialties of the total group of specialists ${ }^{(29)}$. In view of the judges' evaluations of the scale model, the level of compliance was compatible with studies of two-dimensional technologies ${ }^{(20,30)}$.

In addition to the correct, valid, and applicable information, it is especially necessary that the health educational material is understandable by the target audience. The use of the scale model as educational gerontotechnology allows to evaluate the main factors that trigger falls based on the reality of the elderly, in addition to identify the legitimate need for information regarding the risks, making it possible to strengthen health-promoting behavior.

The use of educational gerontotechnology subsidized by the Health Promotion Model makes feasible the individual and contextualized care, since the HPM defends that each individual has personal characteristics and single experiences, which affect their actions regarding promotion of health ${ }^{(23)}$. Thus, educational actions that take into consideration these aspects has greater potential to reach the objectives proposed, since gerontotechnology, sometimes, is not a product, but the result of a job that involves a set of actions that aim the healthcare ${ }^{(31)}$.

The HPM is being used in the search for health-promoting behaviors for several areas and diseases, reaching satisfactory results ${ }^{(31-32)}$. These examples strengthen the importance of the use of educational technologies approved by theoretical models for health promotion actions, identifying the factors that influence healthy behaviors of individuals ${ }^{(33)}$.

In the field of gerontology and gerontotechnology, the HPM has been used as theoretical benchmark; as examples, it is found surveys that analyzed the construction of self-care actions for the elderly through the identification of factors that influence healthy behaviors and the development of applications for the promotion of health of the family caregiver of dependent elderly ${ }^{(33-34)}$.

The elderly participation in the evaluation process of educational gerontotechnology for the prevention of falls in this population, observed the recommendations regarding the participation of the interested individuals as essential element for the development of an appropriate technology, and with higher chance to reach the proposed goals ${ }^{(35)}$.

\section{Study limitations}

It is important to highlight that the transportation of the scale model was difficulty due to its weight and size. Respecting the considerations of the judges and the elderly, which involve the addition of a service area/backyard, a second floor, corridors and stairs, a new prototype is already being envisioned, possibly using a 3D printer or a lower density material that, consequently, will let the scale model lighter, even with the addition of areas requested. A clinical validation of the use of the model is also necessary to evaluate its effectiveness in reducing falls in the elderly.

\section{Contributions to the field of nursing, health or public policy}

The development of this gerontotechnology contributes to the nurse's practice and other health providers, and it can be applied in different scenario of care to the elderly, family, and caregivers. Driven by the dialog and experience exchange, the use of the scale model provides a critical-reflexive posture of the elderly before their shared responsibility in the prevention of falls, favoring the promotion of health.

The nurse may use this gerontotechnology in order to facilitate the visualization of possible fall risks at home, as well as present strategies in the prevention of the disease and, consequently, reduce damages arose from it, both in the physical aspect, such as fractures and injuries, or reducing expenses for the health system resulting from hospitalizations and rehabilitation due to falls.

\section{CONCLUSION}

Educational gerontotechnology of scale model type was considered valid to be used in health promotion strategies in different contexts. In addition, it has potential to contribute with the identification of falls risk inside home, either for the elderly or to the general population. However, it still needs improvements regarding its structure.

\section{REFERENCES}

1. Bezerra IMP, Machado MFAS, Duarte AS, Costa EAP, Antão JFL. Communication in the Educational Process Developed by Nurses: technology in health analysis. Saude Transf Soc[Internet]. 2014[cited 2019 Jan 5];5(3):42-8. Available from: http://incubadora.periodicos.ufsc.br/index. $\mathrm{php} / \mathrm{saudeetransformacao/article/view/2448/3994}$

2. Albuquerque AFLL, Pinheiro AKB, Linhares FMP, Guedes TG. Technology for self-care for ostomized women's sexual and reproductive health. Rev Bras Enferm. 2016;69(6):1164-71. doi: 10.1590/0034-7167-2016-0302

3. Olympio PCAP, Alvim NAT. Board games: gerotechnology in nursing care practice. Rev Bras Enferm. 2018;71(2):818-26. doi: 10.1590/0034-7167-2017-0365 
4. Ilha S, Santos SSC, Backes DS, Barros EJL, Pelzer MT, Costenaro RGS. Complex educational and care (geron)technology for elderly individuals/families experiencing Alzheimer's disease. Rev Bras Enferm. 2017;70(4):726-32. doi: 10.1590/0034-7167-2016-0687

5. Antes DL, Schneider IJC, Benedetti TRB, D'Orsi E. Fear of recurrent falls and associated factors among older adults from Florianópolis, Santa Catarina State, Brazil. Cad Saúde Pública[Internet]. 2013[cited 2019 Jan 5];29(4):758-68. Available from: http://www.scielo.br/pdf/csp/ v29n4/13.pdf

6. Park SH. Tools for assessing fall risk in the elderly: a systematic review and meta-analysis. Aging Clin Exp Res[Internet].2018[cited 2019 Jan 5];30(1):1-16. Available from: https://www.ncbi.nlm.nih.gov/pubmed/28374345

7. Hopewell S, Adedire O, Copsey BJ, Boniface GJ, Sherrington C, Clemson L, et al. Multifactorial and multiple componente interventions for preventing falls in older people living in the community. Cochrane Database Syst Rev [Internet]. 2018[cited 2019 Jan 30];23:7. Available from: https://www.ncbi.nlm.nih.gov/pubmed/30035305

8. Saad PM. Envelhecimento populacional: demandas e possibilidades na área de saúde envelhecimento populacional: demandas e possibilidades na área de saúde [Internet]. 2016[cited 2019 Jan 30]. Available from: http://www.abep.org.br/publicacoes/index.php/series/article/view/71/68

9. Wiemeyer J, Kliem A. Serious games in prevention andre habilitation - a new panacea for elderly people? Rev Aging Phys Act[Internet]. 2012[cited 2019 Jan 30];9(1):41-50. Available from: https://eurapa.biomedcentral.com/articles/10.1007/s11556-011-0093-x

10. Hamm J, Money A, Atwal A. Fall Prevention Self-Assessments Via Mobile 3D Visualization Technologies: Community Dwelling Older Adults' Perceptions of Opportunities and Challenges. JMIR Hum factors[Internet]. 2017[cited 2019 Jan 30];4(2):15. Available from: https://www.ncbi. nlm.nih.gov/pubmed/28630034

11. Macdonald AS, Loudon D, Rowe PJ. Visualisation of biomechanical data to assist therapeuticre habilitation. Gerontechnology[Internet]. 2010[cited 2019 Jan 30];9(2):98-9. Available from: https://www.ncbi.nlm.nih.gov/pubmed/22318480

12. Alaviani M, Khosravan S, Alami A, Moshki M. The effect of a multi-strategy program on developing social behaviors based on Pender's Health Promotion Model to prevent loneliness of old women referred to Gonabad Urban Health Centers. IJCBNM. 2015;3(2):132-40. Available from: https://pubmed.ncbi.nlm.nih.gov/26005693/

13. Malta M, Cardoso LO, Bastos Fl, Magnanini MMF, Silva CMFP. Iniciativa STROBE: subsídios para a comunicação de estudos observacionais. Rev Saúde Pública. 2010;44(3):559-565. doi: 10.1590/S0034-89102010000300021

14. Money AG, Atwal A, Young KL, Day Y, Wilson L, Money KG. Usingthe Technology Acceptance Modelto explore community dwelling older adults' perceptions of a 3D interior design application to facilitatepre-discharge home adaptations. BMC Med Inform Decis Mak[Internet]. 2015[cited 2019 Jan 30];15(1):73. Available from: https://bmcmedinformdecismak.biomedcentral.com/articles/10.1186/s12911-015-0190-2

15. Brandão CF, Collares CF, Marin HF. Realistic simulation as an educacional tool for medical students. Sci Med[Internet]. 2014[cited 2019 Mar 4];24(2):187-92. Available from: http://revistaseletronicas.pucrs.br/ojs/index.php/scientiamedica/article/view/16189/11485

16. Almeida RD. O Do desenho ao mapa: iniciação cartográfica na escala. São Paulo: Contexto; 2001.

17. Lima ACMACC, Bezerra KC, Sousa DMN, Rocha JF, Oriá MOB. Development and validation of a booklet for prevention of vertical HIV transmission. Acta Paul. Enferm. 2017;30(2):181-9. doi: 10.1590/1982-0194201700028

18. Catunda HLO, Bernardo EBR, Vasconcelos CTM, Moura ERF, Pinheiro AKB, Aquino PS. Methodological approach in nursing research for constructing and validating protocols. Texto Contexto Enferm. 2017;26( 2 ):e00650016. doi: 10.1590/0104-07072017000650016

19. Polit DF, Beck CT. Fundamentos de pesquisa em enfermagem: avaliação de evidências para a prática da enfermagem. 7 ed. Porto Alegre: Artmed;2011. 344-669 p.

20. Alves AM. Construção e validação de cartilha educativa para prevenção de quedas em idosos [Dissertação] [Internet]. Fortaleza: Universidade Federal do Ceará; 2017 [cited 2019 Jun 14]. Available from: http://repositorio.ufes.br/bitstream/10/10592/1/tese_12677_ DISSERTA\%c3\%87\%c3\%830\%2013_10_2018\%20\%282\%29.pdf

21. Barros CFM. Casa segura: uma arquitetura para a maturidade. Rio de Janeiro: Papel \& Virtual; 2000.

22. Pender NJ, Murdaugh CL, Parsons MA. Health Promotion in Nursing Practice. 7 ed. Pearson: Boston; 2014.

23. Neto JAC, Braga NAC, Brum IV, Gomes GF, Tavares PL, Silva RTC, et al. Awareness about falls and elderly people's exposure to household risk factors. Ciênc Saúde Colet[Internet]. 2018[cited 2019 Mar 10];23(4):1097-104. Available from: http://www.scielo.br/pdf/csc/v23n4/en_14138123-csc-23-04-1097.pdf

24. Áfio ACE, Balbino AC, Alves MDS, Carvalho LV, Santos MCL, Oliveira NR. Analysis of the concept of nursing educational technology applied to the patient. Rev Rene[Internet]. 2014[cited 2019 Mar 4];15(1):158-65.Available from: http://periodicos.ufc.br/rene/article/view/3109

25. Barros IFO, Pereira MB, Weiller TH, Anversa ETR Hospitalizations due to falls among elderly Brazilians and related costs under the Public Health System. Rev Kairós Gerontol [Internet]. 2015[cited 2019 Mar 10];18(4):63-80. Available from: https://revistas.pucsp.br/kairos/article/ view/26930/19124

26. Kamei T, Kajii F, Yamamoto Y, Irie Y, Kozakai R, Sugimoto T, et al. Effectiveness of a home hazard modification program for reducing falls in urban community-dwelling older adults: A randomized controlled trial. Jpn J Nurs Sci[Internet]. 2015[cited 2019 Mar 10];12(3):184-97. Available from: https://www.ncbi.nlm.nih.gov/pubmed/25212766

27. Smith AA, Silva AO, Rodrigues RAP, Moreira MASP, Nogueira JA, Tura LFR. Assessment of risk of falls in elderly living at home. Rev Latino-Am Enfermagem[Internet]. 2017[cited 2019 Mar 10];25:e2754. Available from: http://www.scielo.br/pdf/rlae/v25/0104-1169-rlae-25-e2754.pdf 
28. Viana LR, Barreto MM, Girard CCP, Teixeira E. Educational technology to mediate educational practices on complementary feeding in the Amazon: validation study. Revista Ibérica de Sistemas e Tecnologias de Informação[Internet]. 2018[cited 2019 Jun 14];(28):29-40. Available from: http://www.scielo.mec.pt/scielo.php?script=sci_abstract\&pid=S1646-98952018000300004\&lng=pt\&nrm=iso\&tlng=en

29. Santos SB, Machado APA, Sampaio LA, Abreu LC, Bezerra IMP. Acquired Syphilis: construction and validation of educational technology for adolescents. J Hum Growth Dev[Internet]. 2019[cited 2019 Jun 14];29(1):65-74.Available from: http://pepsic.bvsalud.org/scielo. php?script=sci_arttext\&pid=S0104-12822019000100009

30. Benevides JL, Coutinho JFV, Pascoal LC, Joventino ES, Martins MC, Gubert FA, et al. Development and validation of educational technology for venous ulcer care. Rev Esc Enferm USP[Internet]. 2016[cited 2019 Jun 14];50(2):306-12. Available from: http://www.scielo.br/scielo. php?pid=S0080-62342016000200309\&script=sci_abstract

31. Mohsenipoua H, Majlessi F, Shojaeizadeh D, Rahimiforooshani A, Ghafari R, Habibi V. Predictors of health-promoting behaviors in coronary artery bypass surgery patients: an application of Pender's health promotion model. Iran Red Crescent Med J[Internet]. 2016[cited 2019 Jun 14]:18(9). Available from: https://www.ncbi.nlm.nih.gov/pubmed/28144467

32. Khodaveisi M, Omidi A, Farokhi S, Soltanian AR. The effect of Pender's health promotion model in improving the nutritional behavior of overweight and obese women. Int J Community Based Nurs Midwifery[Internet]. 2017[cited 2019 Jun 14]:5(2):165.Available from: https:// www.ncbi.nlm.nih.gov/pubmed/28409170

33. Silva ACS, Santos I. Promoting the self care of the elderly for healthy aging: application of nola pender theory. Texto contexto - enfer [Internet]. 2010[cited 2019 Mar 4];19(4):745-753. Available from: http://www.scielo.br/scielo.php?script=sci_abstract\&pid=S0104-07072010000400018\&ln $\mathrm{g}=$ en\&nrm=iso\&tlng=en

34. Souza CAW, Olympio PCAP. Promoção da saúde do cuidador familiar de idosos dependentes: uma gerontotecnologia baseada na teoria de nola pender [dissertação] [Internet]. Espirito Santo: Universidade Federal do Espirito Santo.2018[cited 2019 Jun 14]. Available from: http:// www.repositorio.ufc.br/handle/riufc/21915

35. Merkel S, Kucharski A. Participatory Design in Gerontechnology: A Systematic Literature Review. Gerontologist[Internet]. 2019 [cited 2019 Jun 14];59(1):16-25. Available from: https://www.ncbi.nlm.nih.gov/pubmed/29788319 